\title{
Remediating Tradition with Technology: A Case Study of From Tangible to Intangible: A Media Showcase of Kisa chin p'yori chinch'an uigwe
}

\author{
Boa RHEE, Federico PIANZOLA, Nayea OH, Gangta CHOI and Jungho KIM
}

[Rhee, B., Pianzola, F., Oh, N., Choi, G., \& Kim, J. (2021). Remediating tradition with technology: A case study of From Tangible to Intangible: A Media Showcase of Kisa chin p'yori chinch'an uigwe. Digital Creativity, 1-15.

https://doi.org/10.1080/14626268.2021.1876093]

\begin{abstract}
This paper presents the remediation of a $19^{\text {th }}$ century Korean manuscript (the 1809 Uigwe) as an interactive digital experience using creative algorithms and gesture recognition developed by LG Electronics. The interactive media we created using sound visualization invites visitors to jointly experience Joseon's royal music and the manuscript's pictorial illustrations. We present the media development process and the results of a survey assessing users' engagement. Our findings show that technological remediation can be a fruitful way to elicit the interest for cultural heritage. The Uigwe media enhanced the participants' curiosity for the 1809 Uigwe, and the added sound of the traditional court music (Yeominlak) and the images of the musical instruments increased users' understanding of the 1809 Uigwe and of royal court music. Overall, the study provides evidence about the use of multisensory digital media for fostering learning experience and cultural appreciation of historical artefacts.
\end{abstract}

Keywords: Korean manuscript, interactive media, gesture interaction, sound visualization, user experience 


\section{Introduction}

In January 2020 the Korea Cultural Center in London presented From Tangible to Intangible: A Media Showcase of Kisa chin p'yori chinch'an uigwe, a project in which the Kisa chin p'yori chinch'an uigwe (hereafter the 1809 Uigwe) manuscript has been remediated in the form of interactive media (hereafter the Uigwe media) using digital technology and gesture interaction. Our goal was to evaluate the efficacy of technological remediation of documentary cultural heritage for increasing the interest of the audience.

The 1809 Uigwe is considered one of the finest items of the Korean collection at the British Library, with the official English title: "Records of the ritual presentation and banquet in the Kisa year (1809)." The great interest of the manuscript lies in the lavishly colored pictorial illustrations which give viewers a great insight into the scale and style of the rituals and ceremonies of the royal culture of the Korean Joseon dynasty, as well as into the finest quality of manuscripts produced for the kings' perusal.

In 2006, Beth Mackillop, a librarian of the East Asian Collection Department at the British Library, introduced the 1809 Uigwe in the documentary Coréen $2495 .^{1}$ The manuscript is currently stored in a light-blocked storage room because traditional Korean pigments and paper are extremely vulnerable to light, and the colors could be easily degraded (Jo et al. 2019). Since access to the 1809 Uigwe is restricted, it has rarely been studied in comparison to other manuscripts of the Joseon Dynasty, and the general audience did not have many opportunities to see it. Digital preservation is a high priority at the British Library in order to permanently preserve the content of their collections (Woodyard 2002). Digitalizing cultural heritage enables the enduring value of physical heritage to be long-term preserved, making it more easily accessible, and widely shared and disseminated to the public (Wang et al. 2020). Making it digital, the real object is not under threat but remains a source and reference for the virtual. In other words, the physical object gives the digital surrogate authenticity (Cameron 2007). The 1809 Uigwe was digitized in 2013 and the digital edition is available online since then. However, engaging museum and library visitors with digital reproductions of manuscripts is not easy. Hence, six years later, a showcase of the 1809 Uigwe was created through global collaborations of industry-academic-cultural institutions and presented during a dedicated event. The British Library provided $4 \mathrm{~K}$ ultra high-resolution digital image data of the 1809 Uigwe, LG Electronics supported hardware and gesture interaction technology, and the research team from the College of Art \& Technology at Chung-Ang University developed an interactive media through the technological remediation and modern interpretation of the 1809 Uigwe.

Here we present the development and evaluation of a novel exhibition system employing gesture interaction based on deep learning and sound visualization - that offers visitors an immersive experience of cultural artifacts. This paper examines the Uigwe media exhibited in the showcase, focusing on the general values and features of the historic piece, the design of user experience elements and gesture interaction, the users' engagement with the Uigwe media, and its potential to foster interest. Since this media combines visual, auditory, and algorithmic techniques for remediating the manuscript, strategies for multisensory engagement and gesture interaction are also discussed. To assess the efficacy of the technology employed for users' engagement, we carried out a survey among participants of the media showcase. The results reflect different perspectives on the Uigwe media, by Koreans and London residents. 


\section{Summary of Kisa chin p'yori chinch'an uigwe}

Uigwe, the royal protocols of the Joseon Dynasty, have been known as the epitome of the documentary culture of the over 500 year-long Joseon Dynasty (Kim 2008). These manuscripts form a comprehensive and systematic collection of writings and pictorial illustrations which are considered a scripture-standard (Shin 2007). Uigwe record every element of the royal ceremonies such as appointments of a Crown Prince, weddings, funerals, banquets, and so on, for the edification of future rulers and generations (Yi 2008; Kim 2008). The Kisa chin p'yori chinch'an uigwe describes both the offering of garment ceremony and the banquet to celebrate the $60^{\text {th }}$ anniversary of Lady Hyegyeong's crowning ceremony (gwallye). In the process of compilation, two volumes were published in March 1809 at Gyujanggak, a royal library at Changdeok Palace, presented to Lady Hyegyong (March 22, 1809) and King Sunjo (March 23, 1809), and then kept in Oegyujanggak, which was the Ganghwa Island branch of Gyujanggak until the middle of $19^{\text {th }}$ century. Another copy was published in September by Yejo with a different name (Hyegyeongchinch'ansouigwe). Of the two existing copies, one was considered destroyed by fire with the building of Oegyujanggak during the invasion of French forces under Admiral Roze, occurred in Ganghwado Island in 1866 (Jung 2007; McKillop 2010). The second was brought to France in 1866-67 with a collection of 300 manuscripts and it is currently in possession of the British Library. According to a document in the archives of the British Library, this royal manuscript was purchased by the British Museum in 1891 for $£ 10$ from a Parisian cheese merchant called H. Fauré. ${ }^{2}$ The 1809 Uigwe was transferred from the British Museum to the British Library on its establishment in 1973.

The 1809 Uigwe consists of 94 leaves, encompassing all the attributes required for the king's perusal in terms of paper quality, binding, calligraphy and illustrations. For example, it was meticulously handwritten on the highest quality paper (Chojuji) and it was equipped with five pieces of nails, brass reinforcements engraved with a chrysanthemum, and a round brass ring. It also provides a faithful record of the ceremony, explaining its organization through words ordered in diagrams (baebando) and pictorial illustrations (banchado). The solemn nature of the event is underlined by the documentary style of the painting (Mckillop 2010). It is notable that only music and songs were performed but no dance, in contrast to what reported in other uigwe and court banquet records. Thanks to the banchado, viewers can get an idea of how court music was performed by the deungga and heonga orchestras (Figure 1). The former, called dangsangak (an ensemble performing on terrace), is a fifty-one musicians terrace orchestra, and the latter, called danghaak (an ensemble performing in the courtyard below the terrace), is a fifty-four musicians platform orchestra (Kim 2015). Compared to other Jinchan uigwe, the existence of these two illustrations makes the 1809 Uigwe special. Interestingly, in the 1809 Uigwe it is clearly stated which orchestra played which music in each ritual procedure. In the case of the banquet, deungga and heonga alternately played and performed, only sometimes playing together (Im 2011; Kim 2018). The concert masters are distinguishable from the other musicians by their green robes. Moreover, these illustrations provide invaluable information about the musicians' position, and about the shape and name of each musical instrument typically used in the royal court music of the Joseon Dynasty. The musicians in the orchestras played a variety of instruments including wind, brass, percussion, and string instruments.

Taking into account the original features of the 1809 Uigwe we designed an interactive media experience with the aim of valorizing aspects related to the music performed during the described ceremony. In particular, we wanted to bring the attention of the audience to the 
instruments' illustrations and their vivid colors, while at the same time increasing the audience's understanding of the sound of ancient instruments.

\section{Development of the interactive media of Kisa chin p'yori chinch'an uigwe}

With the ongoing advancements of data science and media technology over the last decades, their coupling with digital cultural heritage has evolved into promising applications for an effective expression of context-sensitive information. From the perspective of data science, presenting data in more visually intuitive and artistic ways opens new possibilities of expression beyond the mere presentation of static visualizations. For instance, data visualization can enable users' direct interaction with data through a media interface and the depiction and exploration of digital cultural heritage in real-time (Trapp et al. 2010).

Researchers in the area of cultural heritage generally agree that new visualization technologies are of paramount importance in disseminating cultural heritage knowledge (Scopigno et al. 2011). Therefore, most cultural heritage applications address visualization using various media or platforms: desktop-based multimedia presentations, museum kiosks, or videos produced with computer animation. With the development of virtual reality (VR), augmented reality (AR), and $3 \mathrm{D}$ multimedia technology, a number of projects related to remediation of cultural heritage have been implemented: Le Mont-St-Michel Hologram and Mixed Reality (Musée des Plans-Reliefs \& Microsoft), Monalisa: Beyond the Glass (Louvre Museum \& Emissive), Digital Michelangelo (Stanford University and University of Washington), Terracotta Warriors of the First Emperor AR (Franklin Institute), Eternal Egypt Project (Supreme Council of Antiquities, CultNat and IBM), Pure Land: Inside the Magao Grottoes at Dunhuang (Sarah Kenderdine, Jeffery Show, Andrew Yip and Laboratory for Innovation in Galleries, Libraries, Archives and Museums) and so on.

Most Korean cultural heritage project using new media technology have been implemented based on tangible artifacts stored at museums and historic sites. Traditional paintings are transformed into digital paintings with projection mapping and motion graphics for the purpose of digital exhibitions. A few media projects have been created using documentary heritage in Korea. For instance, the Return of Oegyujanggak uigwe from France: Records of the State Rites of the Joseon Dynasty was held at the National Museum of Korea in 2011, including a 3D animation. Another notable example is Visual Genealogy (Park et al. 2016), which presents serial information visualizations of two generative artworks based on family tree data. However, neither the 3D animation of Oegyujanggak uigwe nor Visual Genealogy have interactive elements or gesture interaction. In this context, our project employs state-of-the-art technology for data visualization and deep learning-based gesture interaction to create an interactive media based on Korean documentary cultural heritage.

During the research process for the realization of the interactive media of the Kisa chin p'yori chinch'an uigwe (hereafter the Uigwe media), our research team focused on sound visualization. Thus, we examined how to express the colorful illustrations of the musical instruments in combination with the sound of the court music played by the deungga and heonga orchestras. Among the 19 songs and musical pieces, Yeominlak and Yeominlakryong were the most frequently played during the ceremony and banquet. For example, when the king and queen bowed to Lady Hyegyeong twice, the deungga and heonga played Yeominlak, and when they gave flowers to Lady Hyegyeong, heonga played Yeominlakryong. Yeominlak was one of the songs created in the reign of King Sejong (1418-1450) among the various pieces of 
royal music preserved by the National Gugak Center. From King Sejong's reign to the late Joseon Dynasty, music was usually performed in court ceremonies and during the entrance and exit of the king. One of our goals was to convey aesthetic pleasure in users of the interactive media by showing the beautiful colors of Heongado and Deunggado as well as the dynamic structural pattern of Yeominlak.

Starting with this idea, our team was inspired by the hybrid data visualization in Visual Genealogy (Park et al. 2016). Thus, we decided to create a visual effect using a particle system to express the colors of the 1809 Uigwe and the music of the ceremony. A particle system is a method for modeling objects with fuzzy shapes such as fire, clouds, lights, and so on. The design of a particle system is not fixed, as its shapes and forms are not completely specified. Thus, a particle system is not a static entity. Such dynamic visualizations have been used in various creative works (Fonteles et.al 2013). We selected ten musical instruments used by the deungga and heonga orchestras to be displayed in a carouse ${ }^{3}$ to which we applied the particle system effect: Eo, Gayageum, Haegeum, Janggo, Pyeon-gyeong, Geongo, Gyobamggo, Bipa, Saenghwang, and Bak (Figure 2). Since the media showcase was planned to be in the UK, in selecting the instruments we also considered foreign audience's possible knowledge of a popular show such as Samulnori - a kind of Korean folk music performed with percussions and of Gayageum, a zither-like string instrument.

Attempts to transform musical information into visual art were initiated by avant-garde artists in the early 20th century. In particular, the group of De Stijl, including Piet Mondrian, sought the principle for organizing formative elements in the rules of music, such as harmonics and counterpoints, noting that music consists of purely abstract elements. The emergence of electronic music in the fifties and sixties required new recording methodologies, and new interpretations of music emerged under the influence of avant-garde and conceptual art (Choe 2010). However, sound visualization has been used as a method for sound analysis and expression since the late 1700s (Gerhard 1999).

In creating the uigwe interactive media, we adopted the following sound visualization technique: the sound volume of Yeominlak was converted into the movement of the particles. We used a recording of Yeominlak that is preserved by the National Gugak Center. Yeominlak consists of 5 chapters but we only used chapter 4 for the visualization. We analyzed the sound source of Yeominlak detecting beat, amplitude and frequency (Figure 3). Korean traditional orchestras consist of instruments with frequency ranges similar to that of contemporary music, that is with clearly distinguishable bass, middle and treble. So, we employed amplitude as a main component to apply to particles.

Depending on the volume of the sound, the movement and quantity of the particles changed: the louder the sound, the richer the particles' density will become. Conversely, the lower the volume, the coarser the particles' density. Each image of the instruments was converted into particles after a certain period of time. The color of the particles was applied by extracting the RGB (Red-Green-Blue) value of the image. The pictorial illustrations used a color palette of yellow, black, red, blue and white, symbolizing the association of colors between the five natural elements. The five primary colors used in court record painting of the late Joseon emphasize the connection between the ruler and the cosmos. As a result, the sound of Yeominlak was visualized in beautifully harmonized colors and movements, allowing the audience to experience the sound and its visual remediation of Yeominlak simultaneously (Figure 4). The particles and the UI have been created with the game engine Unity 3D. We 
carefully chose the volume and distribution of particles: at first, we wanted to generate more than 100,000 particles, however, due to hardware performance limitations, we reduced the number of maximum particles to less than 50,000. To counterbalance the sparsity of particles and make the space look more richly filled, we used the Trail Module of Unity particle system, creating an afterimage on the particles, also limiting the particle duration to 3 seconds to avoid user boredom and fatigue.

\section{Finger gesture and user interface}

In the context of Human Computer Interaction (HCI), the primary goal of gesture recognition is to create a system which can identify specific hand gestures, and use them to convey information or for device control without the help of any marker or gloves (Stößel \& Blessing 2009; Hongyong \& Youling 2012). Our gesture recognition system, developed by LG Electronics Convergence Center, has two main functions: the first is to detect the position of the finger in the image coming from a webcam, the second is to recognize certain hand shapes as gestures. To create a deep-learning model able to recognize both, the algorithm has been trained with many hand images to increase the accuracy of each function. As the result of training, the gesture recognition system can recognize the following hand gestures: 'Welcome,' when showing the palm; 'Direction,' when pointing left or right; and 'Pinch' of thumb and index finger. It also detects left and right hand and their fingers to locate positions of each fingertip (Figure 5). During the user experience (UX) design process, we eventually chose to use only four gestures: Welcome, Direction (right, left), and a finger gesture using the index finger (Figure 6).

Our media system consisted of a transparent display, a webcam and a personal computer (Figure 7). The LG Transparent OLED display was the primary information source of the Uigwe media, while the translated text and annotations were positioned on the right side of the display. A webcam, attached to the bottom of the display stand, was used to recognize users' gestures in real time and the transparent display was used to present a sound visualization as the output of users' physical gesture interaction with the system.

The Uigwe media user experience begins with the welcome gesture in order to start the visualization of the manuscript cover and then the carousel of instruments. Each instrument is first visualized as an animation of floating particles, which assembles themselves to form the instruments drawing, and then disassemble again into floating particles (Figure 8).

Users could continue the experience by using the direction gestures to move to the next musical instrument in the carousel (the musical instruments were arranged in a circle). For each musical instrument, users could use the index finger gesture to allow particles to stick and move along the tip of the user's index finger (Figure 9).

\section{The evaluation of the user experiences with the Uigwe media}

Our primary concern in evaluating the Uigwe media was to assess how users perceive the values and qualities associated with it: can the Uigwe media inspire curiosity and foster learning? Can the Uigwe media evoke a sense of authentic experience in terms of art appreciation? Does the Uigwe media experience vary by nationality of the audience? Can the 
technology and Yeominlak used in the Uigwe media enhance the aesthetic experience? In order to examine the participants' engagement with the Uigwe media, we adopted the concepts of Perceived Usefulness (hereafter PU) and Perceived Ease of Use (hereafter PEOU), which are dimensions of the Technology Acceptance Model (TAM) (Venkatesh and Davis 2000), a measure widely used to assess engagement with digital exhibitions (Rhee and Kim 2918; Baek and Rhee 2019). In this study, PU includes both the cognitive and emotional functions of the Uigwe media. On the other hand, PEOU is used to examine the easiness of gesture interaction with the Uigwe media. In addition, we also measured the usefulness of Yeominlak, the usefulness of the images of the musical instruments, the degree of satisfaction, the intention to reuse and the intention to recommend the Uigwe media to others, and previous experience with and knowledge about the 1809 Uigwe.

75 people attended the opening ceremony of $<$ From Tangible to Intangible: A Media Showcase of Kisa chin p'yori chinch'an uigwe $>$ held at the Korea Cultural Center on the $9^{\text {th }}$ of January $2020 .{ }^{4}$ To measure the overall user experiences with the interactive media, we used a quantitative research methodology. We asked the attendees at the opening ceremony to take part in an online survey and 26 participants subsequently answered to 30 statements related to the media on a 5-point Likert scale $(1=$ strongly disagree and $5=$ strongly agree $)$. Following the data collection, we performed frequency analysis and correlation analysis. Almost all participants had experience with traditional Korean culture $(96.1 \%)$ and all of them $(100 \%)$ had attended Korean cultural exhibitions. ${ }^{5}$ As for previous experience and knowledge, more than a half of survey participants had knowledge about the 1809 Uigwe $(61.5 \%)$ and Oegyujanggak uigwe (50.0\%), and $46.2 \%$ of participants viewed the 1809 Uigwe prior to attending the opening ceremony. $92.3 \%$ of participants had experiences with interactive media, however, only $40.0 \%$ of participants experienced media using gesture interactions among them.

We adopted a user-experience questionnaire and asked participants to define their experience with the Uigwe media (Pine and Gilmore 1988). According to the frequency analysis, the Uigwe media has much higher educational value $(57.7 \%)$ than aesthetic $(30.8 \%)$ and entertainment value (11.5\%). Similarly, the suitability for learning was considered higher than that for appreciation. In particular, participants who previously saw the digital version of the uigwe were more likely to think that the media installation helps to better understand the uigwe $(r=.49, p=.01)$. The Uigwe media also enhanced the participants' interest and curiosity about the 1809 Uigwe (100\%), stimulating their desire to see the 1809 Uigwe at the British Library (84.6\%). There was a strong positive correlation between appreciation of the Uigwe media and desire to see the original manuscript $(r=.73, p<.001)$. In particular, this desire was likely motivated by fun $(r=.56, p=.003)$ and satisfaction $(r=.44, p=.02)$ in interacting with the Uigwe media.

The value of the Uigwe media in terms of conveying an authentic experience with uigwe was rated relatively low. However, this might be a bias of the audience, since participants who saw the original manuscript were more likely to think that the media installation presents a value similar to the original version in terms of authenticity $(r=.49, p$ $=.01)$. Nationality seems also to affect this aspect of the experience, since UK participants were less likely to think that the Uigwe media conveyed an authentic experience $(r=-.44, p$ $=.03)$. Table 1 summarizes the results regarding the cognitive and emotional values of the Uigwe media. Notably, when asked about confronting the value of the original manuscript and the interactive media, British and Korean expressed remarkably different perspectives with respect to both emotional and cognitive factors. 
The images of the traditional musical instruments and Yeominlak used in the Uigwe media were positively rated. According to the data, the images of the instruments properly reflected the characteristics of the 1809 Uigwe (84.6\%), presented the characteristics of the royal court music $(88.5 \%)$, and helped enhance the understanding of the royal court music $(80.8 \%)$. The images of the instruments prior to generating the particle effects also promoted the participants' understanding of the flow of experience with the Uigwe media $(76.9 \%)$. Among the ten musical instruments, Eo (50\%) - a tiger-shaped wooden scraper - was the most highly rated compared to other musical instruments, followed by Bak (26.9\%), Geongo (23.1\%) and Saenghwang (23.1\%). ${ }^{6}$ Unlike Korean participants, UK participants liked Pyongyeong a stone chime with sixteen marbles - as the second best. Regarding Yeominlak, $88.4 \%$ of participants agreed that it is well harmonized with the atmosphere of the 1809 Uigwe $(88.4 \%)$, enhancing its understanding $(88.4 \%)$, moreover it increased the feeling of immersion in the Uigwe media (73.1\%). Overall, UK participants rated sound more positively than Koreans. In particular, none of them thought that the sounds disturbed the interaction with the Uigwe media. The majority of participants $(80.8 \%)$ also pointed out that they would have liked to hear the sound of each musical instrument prior to seeing the particle effects.

The overall degree of satisfaction $(84.6 \%)$, the intention to reuse $(80.8 \%)$ and the intention to recommend the media to others $(84.6 \%)$ turns out to be quite high. The reasons for the high degree of satisfaction can be linked to the following properties of the media: the ways of creative visual storytelling (84.6\%), the technological innovation $(80.8 \%)$, the LG transparent display $(80.7 \%)$, the gesture interaction $(77.0 \%)$, the hedonic value $(84.6 \%)$, the sound of Yeominlak $(84.6 \%)$, the immersive feature $(80.7 \%)$ and the high resolution images $(80.7 \%)$. More than a half of the participants $(61.6 \%)$ wanted to take a photo of the media for the purpose of posting images on Instagram and other social media. UK $(r=-.42, p=.03)$ and older participants $(r=-.45, p=.02)$ were less likely to do so. Negative effects in experiencing the media were not correlated with age $(r=.07, p=.75)$ but frequent museum visitors were more likely to be bored $(r=.55, p=.004)$ and feel both mental $(r=.48, p=.01)$ and physical $(r=.49, p=.01)$ fatigue when interacting with the media installation. Although, in general, $76.9 \%$ of the participants agreed that the media do not cause any physical fatigue.

From the technological point of view, only $30.7 \%$ of participants $(53.8 \%$ of Korean participants; $7.7 \%$ of UK participants) recognized that the particle effect was created using the sound of Yeominlak and only 23\% that it was related to RGB values (Red-Green-Blue) of the pictorial illustrations of the 1809 Uigwe $(30.8 \%$ of Korean participants; $15.4 \%$ of UK participants). The suitability of the particle effect used in the Uigwe media was rated quite positively $(65.3 \%)$, both in terms of colors $(80.7 \%)$ and speed of the particle effect $(61.5 \%)$. The data show that the particle effect influenced the degree of immersion (72\%), enjoyment (73.1\%), interest for the Uigwe media (69.3\%), and it helped to properly present the beauty and excellence of the 1809 Uigwe (72\%). Regarding the media interface (PEOU), its usability was rated more highly by UK participants, while the usability of gesture was rated more highly by Koreans. The overall evaluation of the media interface is rated slightly lower than the PU factors (Table 2).

For both UK and Korean participants, the gesture interaction and the guide for interaction were not hard to learn. More than half of the participants pointed out a lack of accuracy the gesture recognition in conjunction with associating the gesture interaction and the generation of particle effects (Table 2). This problem not only resulted in low accuracy of the 
gesture recognition $(11.5 \%)$, but also induced to repeat the gesture interactions $(65.4 \%)$. Consequently, one-third of participants (30.7\%) got frustrated when the gesture interaction did not work properly. This problem is partly due to the lack of users' experiences with gesture interactions, but also an inherent software issue due to the gesture recognition SDK and to environmental factors such as illumination. More specifically, if the amount of light was too much or too little, the camera did not properly recognize the user's hand, and the user's height also affected the camera's gesture recognition. In addition, left-handed persons have not been properly considered in developing the user experience of the Uigwe media.

\section{Conclusion}

Technology is applied for cultural heritage for various tasks such as creation, storage, monitoring, dissemination, presentation and preservation. Applying state-of-the-art media technology like transparent displays and CNN (Convolutional Neural Network) gesture-based interaction with tangible cultural heritage is valuable not only for a new appreciation of cultural heritage but also for improving public access to different forms of cultural resources. In particular, the digitalization of cultural heritage allows to spread it more widely and increase access over time (Wang et al. 2020). The research presented here showed the values and features of the 1809 Uigwe, the process of designing an interactive media for the dissemination of knowledge and cultural appreciation, and users' engagement with the media. The 1809 Uigwe records the court banquet and the offering of garment ceremony in the honor of Lady Hyegyeong and it features all the attributes of excellence of the uigwe created for the king's perusal in terms of calligraphy, illustrations, production materials, and binding. Namely, the lavishly colored pictorial illustrations provide invaluable information about the royal court music of Joseon Dynasty. As the title of the showcase implies, the core of our research was to transform the tangible cultural heritage into intangible interactive media, while simultaneously combining the data of tangible cultural heritage with the intangible court music. We also tried to convey to a wide audience both the aesthetic enjoyment and the knowledge that derives from browsing the 1809 Uigwe, a manuscript whose access is strictly regulated.

All the people who attended the inauguration and participated to our survey were familiar with Korean culture and more than half of them knew the 1809 Uigwe and the Oegyujanggak uigwe. To sum up the results of the analysis regarding Perceived Usefulness (PU) and Perceived Ease of Use (PEOU), the usefulness and suitability of the cognitive factors of the Uigwe media were deemed more valuable than emotional factors. In particular, the Uigwe media was somewhat not suitable to convey an authentic experience of the Uigwe, revealing that digital art is mostly seen as a reproduction of the original tangible artefacts. UK participants were quite critical about the value of authenticity of the Uigwe media. However, the overall appreciation of the Uigwe media increased participants' interest and curiosity about the 1809 Uigwe and stimulated their motivation to experience the 1809 Uigwe at the British Library.

Overall, the majority of the participants agreed that the images of the traditional musical instruments and the sound of Yeominlak properly represent the characteristics of the royal court music and enhance understanding of the 1809 Uigwe, immersion, and interest for Korean traditional musical instruments. Our findings show that the participants' attitude toward the media, including the degree of satisfaction, the intention to reuse and the intention to recommend the media to others, were relatively high. Compared with other satisfaction factors, 
creative visual storytelling, the sound of royal music and the playfulness of the media were preferred the most. On the other hand, the media interface and the gesture interaction revealed some usability issues that require technological improvement. The malfunction of the gesture recognition was the main cause of the low accuracy of gesture recognition, causing repetition of gestures.

From Tangible to Intangible: A Media Showcase of Kisa chin p'yori chinch'an uigwe provided an opportunity to exhibit and spread the knowledge and cultural significance of the 1809 Uigwe outside Korea for the first time. Further research is required but our study showed the significant efficacy of the Uigwe media as a multisensory, immersive digital medium for promoting motivation to learn and cultural appreciation. By interacting with the Uigwe media, participants have not only learned about the 1809 Uigwe but also gathered valuable insight about traditional Korean musical instruments and music. Moreover, the majority of participants at the opening ceremony of the showcase emphasized that the Uigwe media played a pivotal role in leading the future development of digital cultural heritage. We hope that this study and the Uigwe media will boost the academic attention on the 1809 Uigwe and promote international cultural cooperation regarding Korean cultural heritage overseas in the near future.

Boa Rhee is professor at the College of Art \& Technology, Chung-ang University. E-mail: boa.rhee@gmail.com

Boa Rhee is a museum technology and museum informatics researcher. Her works have currently focused on through the transdisciplinary approaches; hyper-connected museum \& museum informatics; mediation between the digital surrogates (i.e. digital exhibitions, VR and AR) and viewers; and social media and museum 3.0. She has published over 60 journal articles and academic books. She has a plenty of experience with implementing media projects and she recently carried out the Project of Kisa chin p'yori chinch'an uigwe. She has served a member of editorial board of International Journal of Art and Culture Technology, International Journal of Art and Culture Education and others. She has also consulted a number of national museums and public museums for 23 years.

Federico Pianzola is researcher at the University of Milan-Bicocca (Italy) and Sogang University (South Korea). E-mail: federico.pianzola@unimib.it

$\mathrm{He}$ received an international $\mathrm{PhD}$ in Italian Literature (University of Florence, University of Cambridge), with a dissertation on aspects of myth in Primo Levi's fictional short stories. His research also concerns narrative theory, digital humanities, and the impact of digital technologies on reading, especially regarding digital social reading and the use of Virtual Reality.

Na-Yae Oh is a doctoral student at the Graduate School of Advanced Imaging Science, ChungAng University. E-mail: onayeayo@gmail.com

Gang-Ta Choi is a student at the master program of Department of Computer Science \& Engineering, Chung-Ang University. E-mail: cminor_delf@naver.com

Jung-Ho Kim is a doctoral student at the Graduate School of Advanced Imaging Science, Chung-Ang University. E-mail: jungho10050@gmail.com 


\section{Acknowledgements}

We would like to express sincere gratitude to British Library, LG Electronics Inc. and the Korean Cultural Center UK who gave us the wonderful opportunity to present $<$ From Tangible to Intangible: A Media Showcase of Kisa chin p'yori chinch'an uigwe>. We are particularly grateful for the London residents who kind-heartedly partook in the post-visit survey. A special thanks also goes to Chung-Ang University for supporting this research and media showcase.

\section{Notes}

1 Coréen 2495, directed by Ha Joon-Soo, is a documentary film deals with the narrative about the journey of Oekyujanggakuigwe.

2 There is a record about the ownership of the manuscript in the British Library's online archive: bought 24 October 1891 from Fromageries Bailleux Adrien, 2 Rue Française, Paris.

3 A carousel is based on a 3D ring-shaped menu rendered on a $2 \mathrm{D}$ display. It is widely used to navigate multimedia catalogs such as web, music, image, video, 3D images and models.

${ }^{4}$ For three weeks, over 550 people in London visited the media showcase of the 1809 Uigwe, which has been featured in newspapers and online media for more than 90 times.

5 The survey participants were librarians and curators (34.6\%) from the Department of the Korean Collection of the British Library, the British Museum and the Victoria and Albert Museum, researchers in the field of the Korean Studies and other area $(26.9 \%)$, professionals in culture and art area $(15.4 \%)$, and general audience who has interest in Korean culture (23.1\%). The ratio of British and Koreans was 50\% respectively. This figure accounts for one third of the attendees at the opening ceremony. The age range of the sample was $20-50$ and the majority $(53.9 \%)$ were over 40 years old.

6 The choices of other musical instruments were: Bipa (3.8\%), Pyeongyeong (15.4\%), Haegeum (7.7\%), Janggu (3.8\%), Gayageum (7.7\%) and Gyobamggo (7.7\%).

\section{Funding}

This research was supported by the Chung-Ang University Research Scholarship Grants in 2018. FP received funding from the European Union's Horizon 2020 research and innovation programme under the Marie Sklodowska-Curie grant agreement No 792849.

\section{References}

Baek, J. S., and Rhee B. A. 2019. "A study on the impact of the suitability for technology on viewing experience with digital exhibition using projection mapping technology." Journal of Heat and Mass Transfer, Special Issue on Advances in Mechanical System and ICTconvergence 1: 163-172.

Cameron, F. "Beyond the cult of the replicant: Museums and historical digital objects: Traditional concerns, new discourses." In Theorizing digital cultural heritage: a critical discourse, edited by Fiona Cameron and Sarah Kenderdine. Massachusetts Institute of Technology, Cambridge, 2007; pp. 49-76.

Choe, S. H. 2010. "A Study on Sound Visualization Based on Music Information Retrieval." Emille: The Journal of the Korean Electro-Acoustic Music Society 8: 33-58.

Gerhard, D. 1999. "Audio visualization in phase space." Bridges: Mathematical Connections in Art, Music and Science: 137-144. 
Fonteles, J. H., Rodrigues, M. A. F., and Basso, V. E. D. 2013. "Creating and evaluating a particle system for music visualization." Journal of Visual Languages \& Computing, 24(6): $472-482$.

Hongyong, T., and Youling, Y. 2012. "Finger tracking and gesture recognition with kinect." In 2012 IEEE 12th International Conference on Computer and Information Technology: 214-218.

Im, M. S. "Court rituals of Joseon dynasty and historical development." Minsokwon, Seoul, 2011.

Jo, S. M., Ryu, S. R., Jang, W. H., Kwon, O. S., Rhee, B. A., and Shin, K. W. 2019. "LED illumination-induced fading of traditional Korean pigments." Journal of Cultural Heritage 37: 129-136.

Jung, S. C. 2007. "Evaluating the negotiation process for the restoration of Korean manuscripts stored at the French National Library." History Journal 16: 193-224.

Kim, J. Y. 2008. "Politics of royal rituals and Banchado illustrations of Uigwe in the late Joseon. Korea Journal 48(2): 73-110.

Kim, J. S. "Sacrificial Rituals and Music. Ritual Music of the Korean Court." In Ritual Music of the Korean Court (Korean Musicology Series 8). National Gugak Center, Seoul, 2015; pp. $29-72$

Kim, J. S. "Bibliographic Review and the Music Historical Value." In A translated version of Kisa chin p'yori chinch'an uigwe with annotation. National Gugak Center, Seoul, 2018; pp. 30-39.

McKillop, B. 2010. "A Royal Manuscript of 1809 in the British Library," Journal of Korean archaeology and art: 176-191.

Park, S. K., Lee, E. J., and Park, J. W. 2016. "Visual History with Choson Dynasty Annals." LEONARDO, 49: 334-341.

Rhee, B. A., and Kim, J. S. 2018. "Mediation between digital surrogates and viewers based on the technology acceptance model." Journal of Theoretical and Applied Information Technology 96 (6): 1668-1679.

Scopigno, R., Callieri, M., Cignoni, P., Corsini, M., Dellepiane, M., Ponchio, F., and Ranzuglia, G. 2011. "3D models for cultural heritage: Beyond plain visualization." Computer, 44(7): 48-55.

Shin, B. Z. 2007. "Culture in Documents from the Joseon Dynasty and Euigwe." The Review of Korean Studies 10(3): 173-183.

Stößel, C., and Blessing, L. 2009. "Is gesture-based interaction a way to make interfaces more intuitive and accessible." In HCI 2009 Electronic proceedings: WS4-Prior Experience. 
http://www.joernhurtienne.com/iuui/Prior_Experience/Position_Papers_files/StoesselBles sing.pdf

Trapp, M., Semmo, A., Pokorski, R., Herrmann, C. D., Döllner, J., Eichhorn, M., and Heinzelmann, M. 2010. "Communication of digital cultural heritage in public spaces by the example of Roman cologne.” In Euro-Mediterranean Conference: 262-276.

Venkatesh, V., and Davis, F. D. 2000. "A theoretical extension of the technology acceptance model: Four longitudinal field studies." Management science, 46(2): 186-204.

Wang, X., Lasaponara, R., Luo, L., Chen, F., Wan, H., Yang, R., and Zhen, J. “Digital Heritage.” In Manual of Digital Earth. Singapore, Springer Nature Singapore, 2020; pp. 565-591.

Woodyard, D. 2002. "Digital preservation at the British Library." Library and Information Research, 26(84): 27-31.

Yi, S. M. 2008. "Euigwe and the documentation of Joseon court ritual life." Archives of Asian Art 58(1): 113-133.
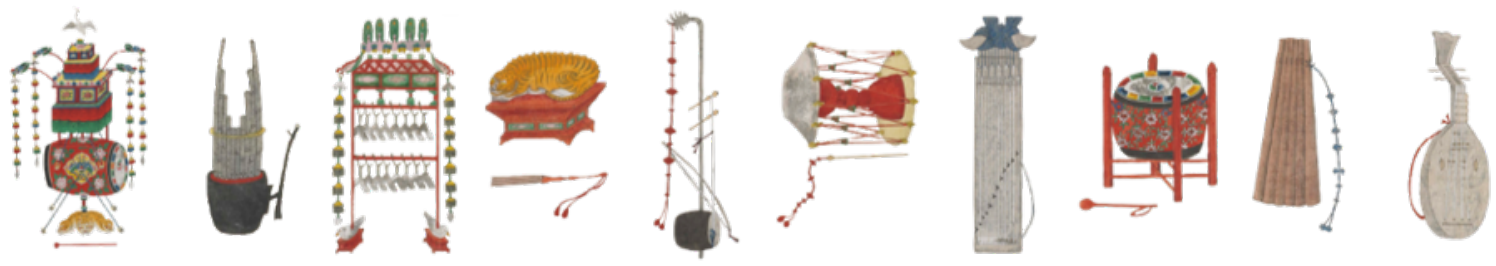

Figure 1
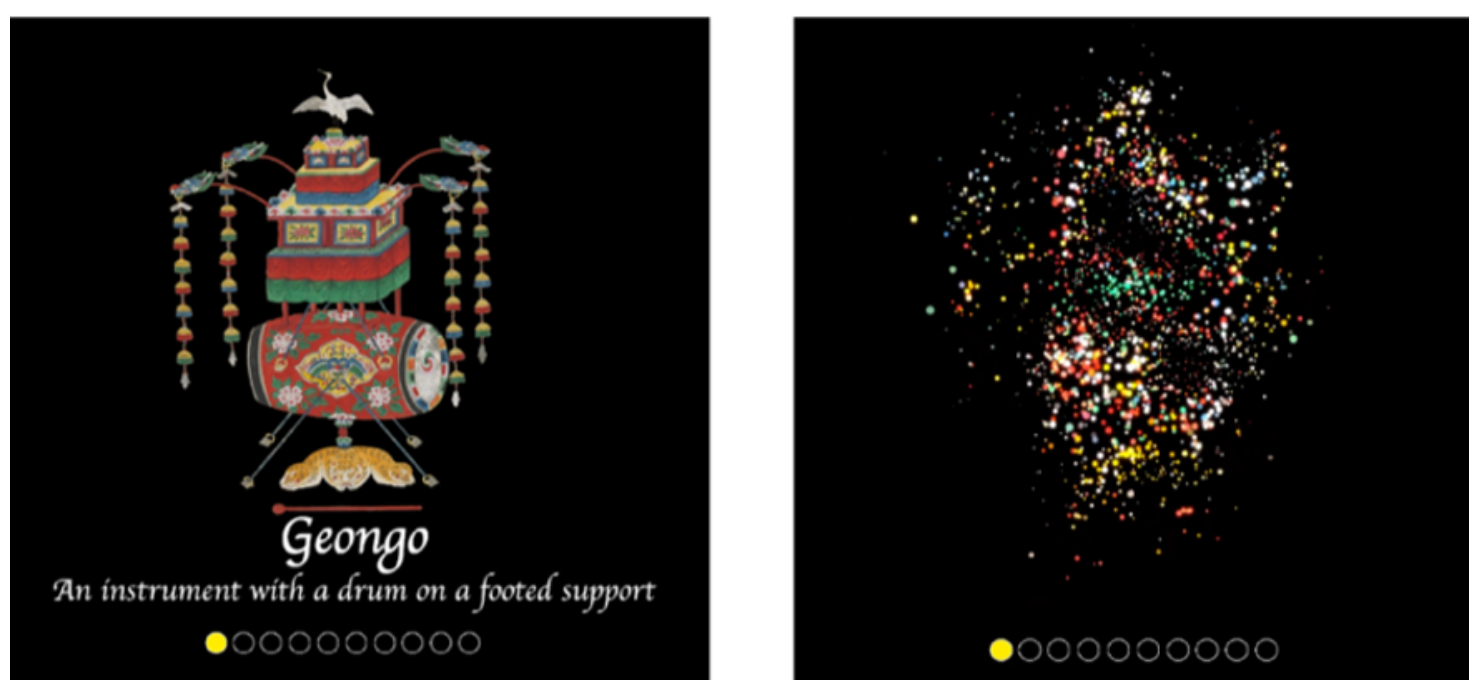

Figure 2 


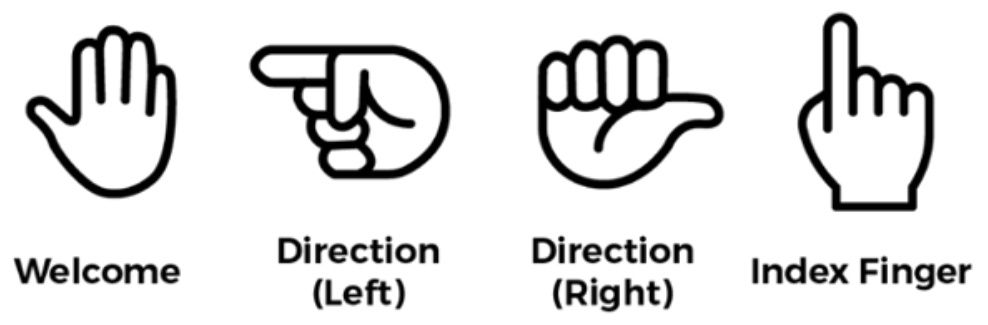

Figure 3
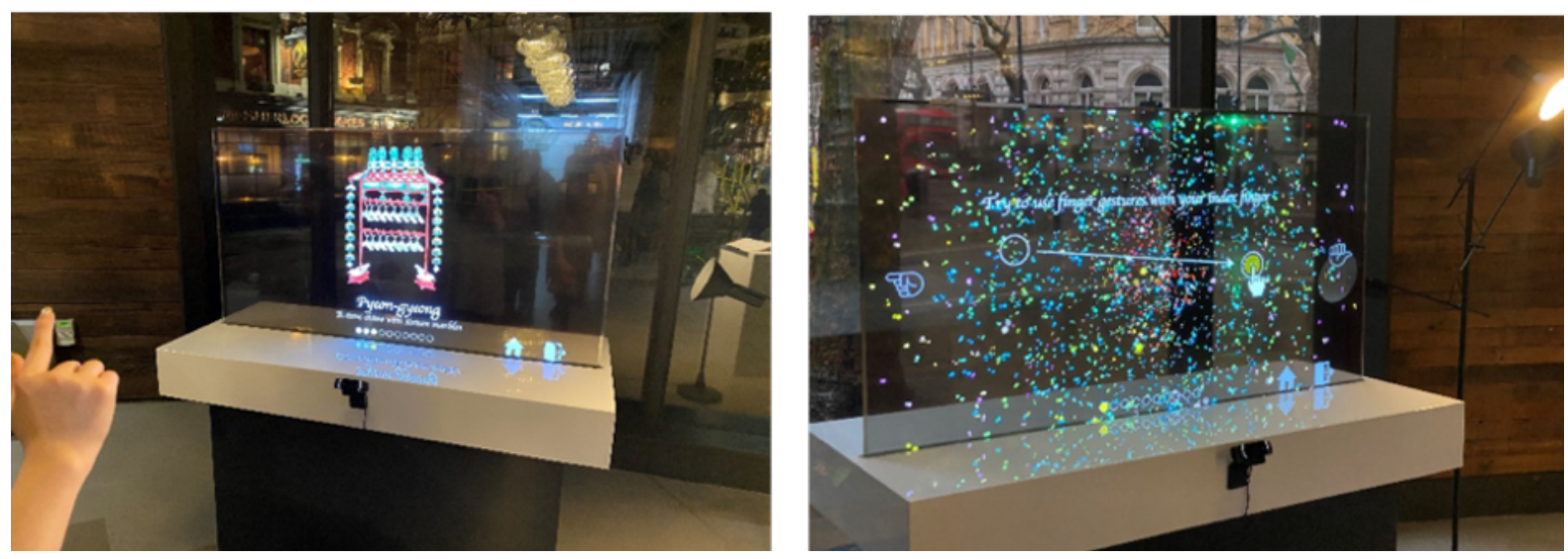

Figure 4

Table 1. Mean values of the PU factors for Korean and UK participants $(n=26 ; \mathrm{SD}=$ standard deviation).

\begin{tabular}{l|l|l|l|l}
\hline PU factor & Detailed function & $\begin{array}{l}\text { Total } \\
(\mathrm{SD})\end{array}$ & $\begin{array}{l}\text { Korean } \\
\text { (SD) }\end{array}$ & $\begin{array}{l}\text { UK } \\
\text { (SD) }\end{array}$ \\
\hline $\begin{array}{l}\text { Cognitive } \\
\text { function of } \\
\text { the media }\end{array}$ & Understanding the meaning of the 1809 Uigwe & 4.04 & 4.25 & 3.92 \\
& & $(0.60)$ & $(0.45)$ & $(0.64)$ \\
\cline { 2 - 6 } & Eliciting interest and curiosity about the 1809 & 4.62 & 4.50 & 4.77 \\
& Uigwe & $(0.50)$ & $(0.52)$ & $(0.44)$ \\
\cline { 2 - 6 } & Encouraging conversation with others & 4.50 & 4.33 & 4.77 \\
& & $(0.76)$ & $(0.78)$ & $(0.60)$ \\
\cline { 2 - 6 } & The Uigwe media is a suitable method for presenting & 3.80 & 4.00 & 3.67 \\
& the knowledge of the 1809 Uigwe & $(0.50)$ & $(0.58)$ & $(0.32)$ \\
\hline \multirow{3}{*}{$\begin{array}{c}\text { Emotional } \\
\text { function of } \\
\text { the media }\end{array}$} & Conveying a similar value of the 1809 Uigwe to the & 2.92 & 3.25 & 2.62 \\
& Uigwe media & $(0.98)$ & $(1.14)$ & $(0.77)$ \\
\cline { 2 - 6 } & Aesthetic pleasure & 4.38 & 4.42 & 4.46 \\
& & $(0.75)$ & $(0.79)$ & $(0.66)$ \\
\cline { 2 - 6 } & Interactivity and immersiveness of the Uigwe media & 4.42 & 4.42 & 4.54 \\
& & $(0.81)$ & $(0.79)$ & $(0.78)$ \\
\cline { 2 - 7 } & The Uigwe media is a suitable method for & 4.15 & 4.33 & 4.08 \\
& appreciating the beauty and excellence of the 1809 & $(0.61)$ & $(0.65)$ & $(0.49)$ \\
\hline & Uigwe & & & \\
\hline
\end{tabular}


Table 2. Mean values of the PEOU factors for Korean and UK participants $(n=26$; SD $=$ standard deviation)

\begin{tabular}{|c|c|c|c|c|}
\hline PEOU Factor & Detailed Factor & $\begin{array}{l}\text { Total } \\
(\mathrm{SD})\end{array}$ & $\begin{array}{l}\text { Korean } \\
\text { (SD) }\end{array}$ & $\begin{array}{l}\text { UK } \\
(\mathrm{SD})\end{array}$ \\
\hline \multirow{6}{*}{$\begin{array}{l}\text { Perceived ease of } \\
\text { use of the media } \\
\text { interface }\end{array}$} & User-friendly interface & $\begin{array}{l}3.85 \\
(0.88)\end{array}$ & $\begin{array}{l}3.83 \\
(1.03)\end{array}$ & $\begin{array}{l}3.92 \\
(0.76)\end{array}$ \\
\hline & Intuitiveness of the interface & $\begin{array}{l}3.88 \\
(0.65)\end{array}$ & $\begin{array}{l}4.00 \\
(0.74)\end{array}$ & $\begin{array}{l}3.85 \\
(0.55)\end{array}$ \\
\hline & Easiness of the gesture icons & $\begin{array}{l}4.12 \\
(0.86)\end{array}$ & $\begin{array}{l}4.08 \\
(0.90)\end{array}$ & $\begin{array}{l}4.23 \\
(0.83)\end{array}$ \\
\hline & Size of gesture icon & $\begin{array}{l}3.96 \\
(077)\end{array}$ & $\begin{array}{l}3.92 \\
(1.00)\end{array}$ & $\begin{array}{l}4.08 \\
(0.49)\end{array}$ \\
\hline & Color of the gesture icon & $\begin{array}{l}4.27 \\
(0.67)\end{array}$ & $\begin{array}{l}4.25 \\
(0.62)\end{array}$ & $\begin{array}{l}4.38 \\
(0.65)\end{array}$ \\
\hline & Easiness of text guide & $\begin{array}{l}3.96 \\
(0.82)\end{array}$ & $\begin{array}{l}4.00 \\
(0.95)\end{array}$ & $\begin{array}{l}4.00 \\
(0.70)\end{array}$ \\
\hline \multirow{7}{*}{$\begin{array}{l}\text { Perceived ease of } \\
\text { use of the AR } \\
\text { gesture }\end{array}$} & Easiness of learning the gesture interaction & $\begin{array}{l}3.50 \\
(1.03)\end{array}$ & $\begin{array}{l}3.75 \\
(1.05) \\
\end{array}$ & $\begin{array}{l}3.31 \\
(1.03) \\
\end{array}$ \\
\hline & Easiness to follow the guide for interaction & $\begin{array}{l}3.65 \\
(0.94)\end{array}$ & $\begin{array}{l}3.83 \\
(1.03)\end{array}$ & $\begin{array}{l}3.54 \\
(0.88)\end{array}$ \\
\hline & Accuracy of the gesture recognition & $\begin{array}{l}2.46 \\
(0.95)\end{array}$ & $\begin{array}{l}2.92 \\
(1.08)\end{array}$ & $\begin{array}{l}2.00 \\
(0.58)\end{array}$ \\
\hline & $\begin{array}{l}\text { Time of interval between the gesture interaction } \\
\text { and the generation of particle effects }\end{array}$ & $\begin{array}{l}2.92 \\
(0.84)\end{array}$ & $\begin{array}{l}2.67 \\
(0.89)\end{array}$ & $\begin{array}{l}3.15 \\
(0.80)\end{array}$ \\
\hline & $\begin{array}{l}\text { Connectivity of the gesture interaction with the } \\
\text { generation of particle effects }\end{array}$ & $\begin{array}{l}3.27 \\
(0.83)\end{array}$ & $\begin{array}{l}3.25 \\
(0.96)\end{array}$ & $\begin{array}{l}3.31 \\
(0.75)\end{array}$ \\
\hline & Natural feature of the gesture interaction & $\begin{array}{l}3.85 \\
(0.67)\end{array}$ & $\begin{array}{l}4.08 \\
(0.67)\end{array}$ & $\begin{array}{l}3.69 \\
(0.63) \\
\end{array}$ \\
\hline & Fatigue caused by the gesture interaction & $\begin{array}{l}3.08 \\
(0.98)\end{array}$ & $\begin{array}{l}3.00 \\
(1.13)\end{array}$ & $\begin{array}{l}3.15 \\
(0.90)\end{array}$ \\
\hline
\end{tabular}

